\title{
The Run Off and Erosion on Eucalyptus Plantation Pt. Toba Pulp Lestari Aek Nauli Sector Simalungun District
}

\author{
${ }^{1}$ Tioner Purba ${ }^{*},{ }^{2}$ Sutrisno \\ ${ }^{1}$ Lecturer in Faculty of Agriculture, Simalungun University, Pematangsiantar \\ ${ }^{2}$ Student in Faculty of Agriculture, Simalungun University, Pematangsiantar
}

\begin{abstract}
Implementing This study aims to determine the amount of surface flow and the amount of erosion on vacant land and stands of Eucalyptus ages 1, 2, 3, 4 and 5 years in HTI PT. Toba Pulp Lestari, Aek Nauli sector. Observations dilakukan runoff and erosion measurements using runoff and erosion at each rain event system by observation of small plots measuring $22 \times 4 \mathrm{~m} 2$ installed on each land cover circumstances. The state of each plot research is in the area of vacant land, stands of age class 1, 2, 3, 4 and 5 years, with $9 \%$ slope. The number of plots a total of 6 plots. And surface flow measurement is done by measuring the volume of water in the drum. Observations magnitude of runoff and sedimentation performed every 2 months during rain events.

The results showed that the surface flow field measurement results showed variation and change in vacant land and a variety of ages eucalyptus. Lowest runoff occurs in the plot of land cover Eucalyptus age 1 year and highest in plots of land cover Eucalyptus age 2 years. The highest erosion rates occurred in plots of vacant land and is followed by a decrease in the Age of Eucalyptus 1,2,3,4 and 5 years.
\end{abstract}

Keywords: Runoff, Surface Flow, Erosion

\section{Introduction}

Industrial Plantation Forest (Hutan Tanaman Industri/HTI) is form of concession to the principle of sustainable forest. In HTI management system uses Artificial Regeneration silviculture Clear Cutting. Felling massive trees and the forest simultaneously both legally and illegally (looting), resulting in open ground at the same time. Rainwater that falls during the rainy season there is no longer blocking the canopy hit the ground so that the ground surface directly, which resulted in the breakup of soil aggregates. Increasing the surface flow and also transport soil particles and organic materials (erosion).

Land clearing is done by clear-cutting can result in land being open and instantly receive beads that can minimize the infiltration of rain water into the ground so as to increase the amount of runoff and eroded soil. Vegetation cover different ground will result in runoff and erosion are different, where vegetation ground cover that would better minimize flow fluctuations. To find great erosion that occurs in stands of eucalyptus ages 1,2,3,4 and 5 years on HTI PT. Toba Pulp Lestari Tbk. Aek Nauli sector, it was observed in the area by making the observation plots at $9 \%$ slope. This study aims to determine the amount of surface flow and the amount of erosion on vacant land and stands of Eucalyptus ages 1, 2, 3, 4 and 5 years in HTI PT. Toba Pulp Lestari, Aek Nauli sector

\section{Materials and Methods}

The experiment was conducted from held under the stands of eucalyptus plantations TPL, Tbk. Aek Nauli sector and the Forestry Research Institute of Soil Laboratory Aek Nauli, Girsangsipangan Bolon Simalungun District. Tools and materials used for this research were: Tally sheet, clinometer, tape measure, Plastics as a barrier wall, Zinc plate as gutters, ombro meters, Drum, Hoes, Parang, Plastic size of $2 \mathrm{~kg}$, measuring cup, filter paper, funnel, Scales electricity, desiccators.

\section{Research Methods}

Runoff and erosion Observations dila $\neg$ kukan runoff and erosion measurements using runoff and erosion for a particular rain event or a particular mass system by observation of small plots measuring 22 x $4 \mathrm{~m} 2$ 
installed on vacant land, stands of age class 1,2, 3, 4 and 5 years, with 9\% slope. And surface flow measurement is done by measuring the volume of water in the drum.

The total volume of runoff calculated by the formula:

$$
\mathrm{V}_{\mathrm{ap}}=\mathrm{V} 1+10(\mathrm{~V} 2)-\frac{\mathrm{E}}{\mathrm{r}}
$$

Remarks: $($ Vap $)=$ total runoff volume (liters / plot),

(V1) = volume of water in the drum of unity (liters),

$(\mathrm{V} 2)=$ volume of water in the drum second (liters),

$(\mathrm{E})=$ erosion $(\mathrm{g} / \mathrm{plot})$,

$(\mathrm{r})=$ density of the contents $(\mathrm{g} / \mathrm{cm} 3)$.

Furthermore, the magnitude of the surface flow is converted from runoff plots measuring $88 \mathrm{~m} 2$ to 1 ha surface flow in the following formula:

$$
\mathrm{V}=\frac{\text { Vap }}{\mathrm{x}} \mathrm{10.000 \text {(liter/ha) }}
$$

88,4

Remarks: $(\mathrm{V})=$ runoff volume in liters / ha, $(\mathrm{Vap})=$ volume flow at the surface of the plot (liters / plot)

As for determining the dry weight of the soil-borne erosion per hectare is:

$$
\mathrm{M}_{\text {per ha }}=\frac{\mathrm{M}_{\text {plot }} \text { X } 10.000}{88 \mathrm{~m}^{2}}(\mathrm{~kg} / \mathrm{ha})
$$

Remarks: (MPER ha) = weight of oven dry soil eroded every day rain events in each hectare $(\mathrm{kg} / \mathrm{ha})$, $($ Mplot $)=$ weight of oven dry soil eroded every day rain events in each plot $(\mathrm{kg})$

\section{Results and Discussion}

\section{Runoff}

Research results showed that the amount of surface runoff, land cover 1,2,3,4,5-year-old Eucalyptus and vacant land is different. Data accumulated surface flow can be seen in Table 1 below

Table 1: The amount of surface flow in Eucalyptus and Land Cover Over Vacant Land

\begin{tabular}{|l|l|l|}
\hline No & Land Cover & Runoff $(\mathbf{m 3 / h a})$ \\
\hline 1 & Eucalyptus 1year & 21,589 \\
\hline 2 & Eucalyptus 2 year & 55,395 \\
\hline 3 & Eucalyptus 3 year & 43,014 \\
\hline 4 & Eucalyptus 4 year & 32,159 \\
\hline 5 & Eucalyptus 5 year & 24,346 \\
\hline 6 & Empty Land & 35,010 \\
\hline
\end{tabular}

Eucalyptus land cover 1 year of age resulted in lower runoff than other Eucalyptus caused kondidi plot of land on the plot of land cover Eucalyptus age 1 year are still many who have not been decaying litter and soil properties such as land clearing forest for a new experience or logging for 1 year. In this plot there are still a lot of root channels (root canal) tree so that rain water can still get into the ground through infiltration 
process. In addition, there's also the remnants of a logging embankments trees, branches, twigs and leaves are not decaying which can serve as a barrier to the flow surface. This is consistent with the results of Farida (2001). Increasing the flow rate at the surface of the plot Eucalyptus age of 2 years is also expected to occur because of this period began to degraded land and litter-litter was decomposed perfectly so that the ability of the soil to pass water and resulted largely reduced rainwater runoff will be.

Condition of the land at the age of 2 years old Eucalyptus plots also occurred on the plots of Eucalyptus 3.4 and 5 years of age, the value of the generated surface flow does not vary much with the plot Eucalyptus age of 2 years, although slightly lower. This shows that land degradation is still going on this period. Impairment runoff on plots of Eucalyptus 3.4 and 5-year estimated the influence of organic materials in the production plant, the roots so as to improve the properties of the soil. Plant roots increase the infiltration capacity of the soil plays, his support in improving the biological activity that will improve porosity, aggregate stability and soil physical and chemical properties (Kartasapoetra, et al., 1967).

Research results indicate that the major erosion on land cover and land vacant Eucalyptus different. Data magnitude of erosion can be seen in Table 3 below.

Table 3: Magnitude of Erosion on Land Cover and Land Blank During Eucalyptus in September and October 2018

\begin{tabular}{|l|l|l|}
\hline No & Tutupan Lahan & Erosi $(\mathbf{K g} / \mathbf{h a})$ \\
\hline 1 & Eucalyptus 1 year & 159,327 \\
\hline 2 & Eucalyptus 2 year & 125,296 \\
\hline 3 & Eucalyptus 3 year & 22,764 \\
\hline 4 & Eucalyptus 4 year & 21,619 \\
\hline 5 & Eucalyptus 5 year & 17,216 \\
\hline 6 & Empty Land & 656,027 \\
\hline
\end{tabular}

The amount of erosion is due to the rainwater that falls on the soil surface, causing shear forces and pressure. Rain water hitting the ground will cause terladinya dispersion and soil consolidation. Rainwater has two forms of energy is potential energy (Ep) and kinetic energy (Ek). To crush the aggregate, potential energy is converted into kinetic energy (Ek) the movement of energy. A trait that is very important in the rain erosion affects the kinetic energy of rain, therefore it is the principal cause of the destruction of soil aggregates (Arsyad, 2006).

From observations in the field show that the closure of the plant canopy of eucalyptus on land cover yangberumur older is better than vacant land. On vacant land there is vegetation. This is vacant land plots with eucalyptus to clear-cutting system. Good canopy closure causes the kinetic energy of rain hitting the ground will be lower, because it was blocked by the tree canopy, so that soil erosion will be lower than the vacant land.

In the plot of vacant land erosion number of observations is much higher than the other plots. This is due to rain (rain beads) that falls directly hits the open ground, causing the crushed aggregates and cover the pores of the soil. Thus resulting in reduced infiltration capacity of the surface so that the flow is accompanied by washout land dispersed greater. Most of the rain that falls, if the rainfall intensity exceeds the infiltration capacity of the soil, will flow over the ground (Arsyad, 2006)

\section{Conclusion}

Surface flow field measurement results showed variation and change in vacant land and a variety of ages eucalyptus. Lowest runoff occurs in the plot of land cover Eucalyptus age 1 year and highest in plots of land cover Eucalyptus age 2 years. The highest erosion rates occurred in plots of vacant land and is followed by a decrease in the Age of Eucalyptus 1,2,3,4 and 5 years. 


\section{References}

[1.] Arsyad, Sitanala. 2006. Konservasi Tanah dan Air. Edisi kedua, Institut Petanian Bogor Press. Bogor.

[2.] Asdak, C. 1995. Hidrologi dan Pengelolaan Daerah Aliran Sungai. Gadjah Mada University Press. Yogyakarta

[3.] Kartasapoetra, A.G. 2000. Teknologi Konservasi Tanah \& Air. Rineka Cipta. Jakarta

[4.] Kartasapoetra,G., A.G. Kartasapoetra, Mul Muyani Sutedjo. 1987. Teknologi Konservasi Tanah dan Air. PT. Bina Aksara. Jakarta

[5.] Ramlan, 2006. Tingkat Reduksi Erosi dan Aliran permukaan terhadap Tanaman Kakao (Theobroma Cocoa L) Dewasa di DAS Nopu. Jurnal Agroland 16 (3) : 213 - 223, September 2009

[6.] Sutisna, UT, Kalima dan Purnadjaja. 1998. Pengenalan Pohon Hutan Di Indonesia. Disunting Oleh Soetjipto, N.W dan Soekotjo. Yayasan PROSEA Bogor dan Pusat Diklat Pegawai \& SDM Kehutanan. Bogor 